\title{
Essential oil of Tagetes filifolia against the flour beetle Tribolium castaneum and its relation to acetylcholinesterase activity and lipid peroxidation
}

\author{
Olmedo, R.; J.M. Herrera, E.I. Lucini, M.P. Zunino, R.P. Pizzolitto, J.S. Dambolena and J.A. Zygadlo
}

\begin{abstract}
SUMMARY
The development of natural insecticides would help to decrease the negative impact of synthetic insecticides. Fumigant toxicity of essential oil of Tagetes filifolia Lag (Asterales: Asteraceae) and its major compounds were evaluated against Tribolium castaneum Herbst (Coleoptera: Tenebrionidae). The essential oils were analyzed by gas chromatography-mass spectrometry. The essential oil and (E)-anethole were the most toxic at $24 \mathrm{~h}$ against adult insects $\left(\mathrm{CL}_{50}=2.4\right.$ y $2.6 \mu \mathrm{L} / \mathrm{mL}$ water, respectively). Changes in the products of lipid peroxidation were evidenced by an increase in malondialdehyde content. Acetylcholinesterase activity in vitro, of $T$. castaneum adults, was also reported. (E)-anethole and estragole showed similar acetylcholinesterase inhibition (54 and $63 \%$, respectively at $5 \mathrm{mM}$ ). The present study constitutes one of the first contributions to understanding the relationship between the insecticidal action of essential oil and oxidative stress.
\end{abstract}

Keywords: fumigant toxicity, Tagetes filifolia, Tribolium castaneum, lipid peroxidation, acetylcholinesterase activity.

Olmedo, R.; J.M. Herrera, E.I. Lucini, M.P. Zunino, R.P. Pizzolitto, J.S. Dambolena y J.A. Zygadlo, 2015. Aceite esencial de Tagetes filifolia contra Tribolium castaneum y su relación con la actividad acetilcolinesterasa y peroxidación de lípidos. Agriscientia 32 (2): 113-121

\section{RESUMEN}

El desarrollo de insecticidas naturales podría ayudar a disminuir el impacto negativo de insecticidas sintéticos. La acción insecticida fumigante del aceite esencial (AEs) de Tagetes filifolia Lag (Asterales: Asteraceae) y sus compuestos principales fueron evaluados contra adultos de Tribolium castaneum Herbst (Coleoptera: Tenebrionidae). Los aceites esenciales fueron analizados por cromatografía gaseosa-espectrometría de masas. El aceite esencial y $(E)$-anetol mostraron mayor toxicidad contra insectos adultos a las $24 \mathrm{~h}\left(\mathrm{CL}_{50}=2,4\right.$ y $2,6 \mu \mathrm{L} / \mathrm{mL}$ water, respectivamente). Se evidenciaron 
cambios en los productos de peroxidación lipídica por un incremento en el contenido de malondialdehído. También se estudió la actividad in vitro de la enzima acetilcolinesterasa de insectos adultos de T. castaneum. (E)-anetol y estragol mostraron similar inhibición de la enzima (54 y 63\%, respectivamente a $5 \mathrm{mM}$ ). El presente estudio constituye una de las primeras contribuciones para comprender la relación entre la acción insecticida del aceite esencial y el estrés oxidativo.

Palabras clave: toxicidad fumigante, Tagetes filifolia, Tribolium castaneum, peroxidación de lípidos, actividad acetilcolinesterasa.

R. Olmedo y E.I. Lucini: Cátedra de Química Biológica,Facultad de Ciencias Agropecuarias, Universidad Nacional de Córdoba, CC 509, 5000 Córdoba, Argentina. J.M. Herrera, M.P. Zunino, R.P. Pizzolitto, J.S. Dambolena and J.A. Zygadlo: Cátedra de Química Orgánica y Productos Naturales. Facultad de Ciencias Exactas, Físicas y Naturales, Universidad Nacional de Córdoba, IMBIV-CONICET-ICTA,. Av. Vélez Sarsfield 1611,Córdoba, Argentina. Correspondence to: pauzun@efn.uncor.edu

\section{INTRODUCTION}

The flour beetle, Tribolium castaneum Herbst (Coleoptera: Tenebrionidae) is a serious insect pest of stored products around the world. Synthetic insecticides such as methyl bromide and phosphine are used for stored-product protection. Current control measures for this species have several limitations.

Methyl bromide affects the ozone layer thus, it has been banned in many countries and there is a commitment to reduce its use in 2015 (Arthur, 2012; Rajashekar et al., 2012). The inadequate and sustained use of phosphine enabled the emergence of resistance in insect populations (Jagadeesan et al., 2012; Opit et al. 2012). Recent studies indicated high levels of phosphine resistance in Brazilian populations of $T$. castaneum (Lorini et al., 2007; Pimentel et al., 2007). Although synthetic pesticides are effective, its frequent use has led to the presence of toxic residues in the environment and in food, and then generates negative effects on human health. These problems have highlighted the need to develop new and safe alternatives based on reducing the use of organophosphate, carbamates and chlorinated insecticides and promote the use of new techniques and products designed to reduce the resistance of insects and their presence in food. Thus, essential oils (EOs) obtained from aromatic plants are recognized as an alternative to synthetic insecticides against insect pest in stored foods (Rajashekar et al., 2012; Regnault-Roger et al., 2012). Plant EOs are promising in that they are easily biodegradable and have not described resistance. With a few exceptions, their mammalian toxicity is low and environmental persistence is short (RegnaultRoger et al., 2012). The genus Tagetes $L$. includes species with medicinal properties and their EOs have insecticidal activity (Krishna et al., 2005; Caballero-Gallardo et al., 2011; López et al., 2011; Stefanazzi et al., 2011). Among Tagetes species, particularly $T$. filifolia (Asteraceae, Helenieae) showed different degree in their insecticidal activity between different groups of insects (Camarillo et al., 2009; López et al. 2011).

The insecticidal activity of EOs and their components can affect different and specific targets (Enan, 2001, 2005; Jbilou et al., 2008; Abdelgaleil et al., 2009; Rattan, 2010; Waliwitiya et al., 2010). However, the inhibitory effect of phenylpropenes on T. castaneum acetylcholinesterase (AChE) of adults, were not reported. Moreover, like synthetic pesticides, EOs could generate oxidative stress. The products of lipid degradation and decomposition are used in assessing oxidative stress, including conjugated dienes (CD), as well as the widely used product malondialdehyde (MDA (Zunino \& Zygadlo, 2004).

Therefore, in the present paper, we investigated the insecticidal activity of T. filifolia EO and their major components against $T$. castaneum. Changes in the products of lipid peroxidation, MDA and CD as indicators of oxidative stress are also discussed. The inhibitory effect on AChE activity of the adult insect was also evaluated. 


\section{MATERIALS AND METHODS}

\section{Insect material}

All experiments were conducted in the laboratory with colonies of the red flour beetle Tribolium castaneum Herbst (Coleoptera: Tenebrionidae). Insects were reared on wheat flour mixed with yeast (10:1, w/w) at controlled temperature and humidity $\left(28{ }^{\circ} \mathrm{C}\right.$ and $\left.70 \% \mathrm{RH}\right)$ and a light/dark regime of 12:12 h (FAO, 1974). Adult insects used in toxicity studies were 3-7 days post-emergence.

\section{Essential oils and pure compounds}

Plants of Tagetes filifolia L. (Asteraceae, Helenieae) were collected from fields around Sierra de Los Gigantes from Córdoba province, Argentina. Specimen plants (Voucher specimen $\mathrm{N}^{\circ}$ 2644) were deposited at the herbarium of Facultad de Agronomía (UNC) Córdoba, Argentina (ACOR).

Plants were dried in the shade to approximately $10 \%$ moisture content. The EO was obtained by hydrodistillation (López et al., 2011) and stored at $-20^{\circ} \mathrm{C}$ in airtight microtubes prior to analysis by gas chromatography-mass spectrometry (GC-MS).

The compounds 1-methoxy-4-[(1E)-prop-1-en-1yl] benzene ((E)-anethole) and 1-methoxy-4-(prop2-en-1-yl) benzene (estragole) were purchased from Sigma Aldrich Co (St. Louis, MO USA) (Figure 1). DDVP (dichlorvos or 2,2-dichlorovinyl dimethyl phosphate) (contains $>98 \%$ of active material, Chemotécnica S.A, Buenos Aires, Argentina) was used as reference insecticide.
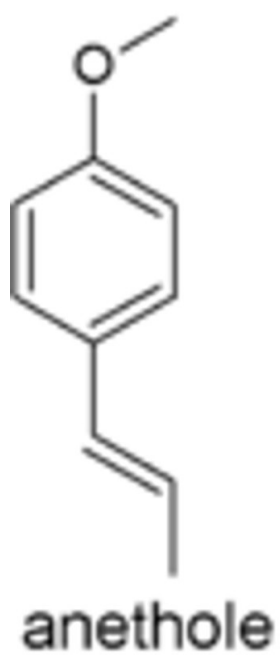

Figure 1. Chemical structures of natural compounds studied in the present work.

\section{Analysis of the essential oil (GC and GC-MS analysis)}

The EO was analyzed using a Perkin-Elmer Clarus 500 gas chromatograph equipped with a flame ionization detector (GC-FID). The gas chromatography analysis was performed using a DB-5 capillary column $(60 \mathrm{~m} 0.25 \mathrm{~mm}$ i.d., film thickness $0.25 \mathrm{~mm}$ ). The carrier gas was helium with a flow rate of $0.9 \mathrm{~mL} / \mathrm{min}$. The oven temperature was maintained at $30{ }^{\circ} \mathrm{C}$ for $5 \mathrm{~min}$ and then programmed at $5{ }^{\circ} \mathrm{C} / \mathrm{min}$ to $250{ }^{\circ} \mathrm{C}$. The injector and detector were maintained at 260 and $280{ }^{\circ} \mathrm{C}$, respectively. The sample, $0.2 \mu \mathrm{L}$, was injected with a 1:100 split ratio.

GC/MS. EOs samples were diluted with hexane. The injection volume was $1 \mu \mathrm{L}$. The identification of the components of the EO was realized by GCMS. A Perkin-Elmer Q 700 GC-MS coupled with an ion trap mass detector was employed for the identification. A capillary column DB-5 (30 m x 0.25 $\mathrm{mm}$ i.d. and $0.25 \mathrm{~m}$ coating thickness) was used for the separation of the components. Helium was used as carrier gas with a flow rate of $0.9 \mathrm{~mL} / \mathrm{min}$. The temperature program for the oven and injector was the same as that for the GC-FID. Ionization was realized by electron impact at $70 \mathrm{eV}$. Mass spectral data were acquired in the scan mode in the $\mathrm{m} / \mathrm{z}$ range $35-450$. Identification of the oil components was based on the comparison of their Retention Indices (RI) and mass spectra with those of authentic samples and/or the Adams, Nist and Wiley Library spectra. RI was computed using a formula by Adams (2007).

\section{Fumigant Toxicity Assay}

Different amounts of EO and pure compounds were placed inside a glass vial $(1.5 \mathrm{~mL})$ onto Petri dish (9 cm diameter). Inside the glass vial was placed $1 \mathrm{~mL}$ of water with the $\mathrm{EO}$ or pure compounds dissolved in ethanol to achieve the appropriate concentration $(0.25-3 \mu \mathrm{L} / \mathrm{mL}$ water $)$ (Figure 2). The ethanol that was added to the medium did not exceed $1 \% \mathrm{v} / \mathrm{v}$. Twenty adults of

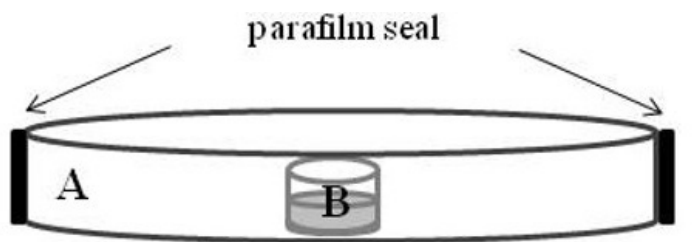

Figure 2: Fumigant toxicity method. A: Petri dish (9 cm diameter) with 20 insects; B: glass vial $(1.5 \mathrm{~mL})$ with $\mathrm{EO}$ or pure compounds dissolved in ethanol/mL water. 
T. castaneum were placed into each Petri dish (4 replicates/doses). The Petri dish was sealed with parafilm to avoid the compounds loss. Insect controls were kept under same conditions without $\mathrm{EO}$ and pure compounds. Insect mortality was checked at 24 and $72 \mathrm{~h}$ of treatment. At $72 \mathrm{~h}$, the EO or pure compounds were evaporated completely and only the vapour phase of the compounds was present in the Petri dish. The mortality percentages and $\mathrm{LC}_{50}$ values were calculated according to Finney (1971).

\section{Lipid Extraction from T. castaneum}

One hundred T. castaneum adults from the different treatments (after $72 \mathrm{~h}$ exposure) were homogenized in $6 \mathrm{~mL}$ of hexane using a glass rod homogenizer. Homogenates were agitated and allowed to stand for $24 \mathrm{~h}$, and then they were filtered through filter paper to remove coarse solids and to rinse the filter system with three portions of $0.5 \mathrm{~mL}$ of hexane. Supernatants were used for determination of MDA and CD content.

\section{Measurement of malondialdehyde (MDA)}

The MDA level was used as an index of lipid peroxidation and was expressed as $\mathrm{nmol} \mathrm{g}^{-1}$ of fresh weight. The MDA content was evaluated using the methodology described by Cervera et al. (2003), with some modification. Briefly, 1 $\mathrm{mL}$ of the supernatant of the lipid extraction was added to $4 \mathrm{~mL}$ of $0.5 \%$ thiobarbituric acid (TBA) in $20 \%$ trichloroacetic acid (TCA). The mixture was incubated at $95{ }^{\circ} \mathrm{C}$ for $30 \mathrm{~min}$ followed by quick cooling over ice and then centrifugated at $10,000 \times g$ for $10 \mathrm{~min}$. The absorbance of the supernatant was read at $532 \mathrm{~nm}$ and corrected for non-specific absorbance at $600 \mathrm{~nm}$. MDA amount was determined using the extinction coefficient of $155 \mathrm{mM}^{-1} \mathrm{~cm}^{-1}$. All the experiments were done in triplicate.

\section{Measurement of conjugates dienes (CD)}

Lipid extraction aliquots $(0.5 \mathrm{~mL})$ were used for determination of $C D$ content. Indices were analyzed spectrophotometrically at a wavelength of $232 \mathrm{~nm}$ (Zunino and Zygadlo, 2004). All the experiments were done in triplicate.

\section{AChE Activity Assay}

T. castaneum adults $(0.5 \mathrm{~g})$ were separately homogenized in $5 \mathrm{~mL}$ of $0.1 \mathrm{M}$ ice-cold phosphate buffer ( $\mathrm{pH}$ 7.4) using a Teflon glass tissue homogenizer. Homogenates were centrifuged (5,000 rpm for $20 \mathrm{~min}$ at $0{ }^{\circ} \mathrm{C}$ ), and supernatants were used as the enzyme source for determination of AChE activity. Inhibition of AChE was determined by the colorimetric method of Ellman et al. (1961) using acetylthiocholine iodide (ATChI) at 0.25 mM (Sigma Aldrich Co., St. Louis, MO USA) as substrate, according to Abdelgaleil et al. (2009), with some modifications. Enzyme aliquots (100 $\mu \mathrm{L})$ and 5,5-dithio-bis (2-nitrobenzoic) acid (DTNB) $(100 \mu \mathrm{L}$ of $0.01 \mathrm{M})$ were added to $0.1 \mathrm{M}$ phosphate

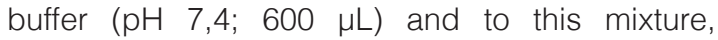
phenylpropene test solutions $(100 \mu \mathrm{L})$ prepared in absolute ethanol were added. Control treatments were prepared by the addition of absolute ethanol $(100 \mu \mathrm{L})$ instead of a phenylpropene. Mixtures were incubated at $35^{\circ} \mathrm{C}$ for $15 \mathrm{~min}$ and reactions were started by adding ATChl (100 $\mu \mathrm{L})$. Absorbance was measured at $412 \mathrm{~nm}$ using UV/VIS Spectrometer, Lambda 25, Perkin Elmer. Tested compounds were examined at two concentrations: $1 \mathrm{mM}$ and $5 \mathrm{mM}$. Each test and control was corrected by blanks for nonenzymic hydrolysis. All the experiments were done in triplicate. Inhibition percentage of AChE activity was calculated as follows:

AChE inhibition $\%=(O D C$ - ODT / ODC $) \times$ 100 , where ODC is the optical density of control and ODT is the optical density of treatment. AChE activity values were compared to the control AChE activity, which was assumed to be $100 \%$.

\section{Statistical analysis}

The lethal concentration $\left(\mathrm{LC}_{50}\right)$ values were calculated according to Finney (1971) using SPSS Statistics program version 17.0 (SPPSS Inc). A one-way analysis of variance was used $(P \leq 0.05)$. Comparisons between treatments were performed by the Duncan's multiple range test. All statistical analyses were calculated by using the InfoStat software Professional 2010 (Di Rienzo et al., 2010).

The data of AChE inhibition was analyzed by one-way analysis of variance. Mean separations were performed by Duncan test and differences at $\mathrm{P}<0.05$ were considered as significant.

\section{RESULTS}

\section{Chemical composition of the essential oil}

The chemical composition of the EO obtained from T. filifolia is shown in Table 1. The main 
constituents of EO were (E)-anethole (74.6\%) and estragole (or methyl chavicol) followed by (E)isoeugenol and anisic aldehyde, as have been described previously by López et al. (2011).

\section{Toxicity of essential oil and its main com- pounds}

The EO of $T$. filifolia was toxic against $T$. castaneum. The toxicity of the $\mathrm{EO}\left(\mathrm{LC}_{50}: 2.0 \mu \mathrm{L} / \mathrm{mL}\right.$ water, at $72 \mathrm{~h}$ ) was higher than that the estragole $\left(\mathrm{LC}_{50}: 5.6 \mu \mathrm{L} / \mathrm{mL}\right.$ water, at $\left.72 \mathrm{~h}\right)$. (E)-anethol was more toxic than estragole both at 24 and at 72 hours of treatment $\left(\mathrm{LC}_{50}: 2.6\right.$ and $2.2 \mu \mathrm{L} / \mathrm{mL}$ water, respectively). However, DDVP was the most toxic compound (Table 2).

\section{Effect of T. filifolia oil and its main components on MDA and CD content of T. castaneum}

The MDA content was positively correlated with increase concentrations of $\mathrm{EO}$ and (E)-anethole, while CD content showed a decrease at $3.0 \mu \mathrm{L} /$ $\mathrm{mL}$ water. Estragole did not affect significantly MDA and CD content at low concentrations. Only at high concentration $(5.2 \mu \mathrm{L} / \mathrm{mL}$ water $)$ it showed significant differences with control in MDA and CD content (Table 3).

Table 1: Chemical constituents of the essential oil from Tagetes filifolia plants collected from Córdoba province, Argentina.

\begin{tabular}{llll}
\hline $\mathrm{R}^{\mathrm{a}}$ & Compound & Content (\%) & Methods of identification \\
\hline 1291 & (E)-anethole & 74.6 & GCMS - Co \\
1194 & estragole & 23.7 & GCMS - Co \\
1455 & (E)- isoeugenol & 0.9 & GCMS - Co \\
1252 & anisic aldehyde & 0.8 & GCMS \\
\hline
\end{tabular}

a Retention index on a DB-5 column relative to homologous series of $n$-alkanes. GCMS: peak identifications are based on MS comparison with file spectra. Co: peak identification is based on standard comparison with relative retention time.

Table 2: Fumigant toxicity of Tagetes filifolia essential oil and their mains components against Tribolium castaneum at $24 \mathrm{~h}$ and $72 \mathrm{~h}$ after exposure.

\begin{tabular}{lcccc}
\hline \multirow{2}{*}{ Compounds } & & & \multicolumn{2}{c}{$\begin{array}{c}\text { confidence limits } \\
(\mu \mathrm{L} / \mathrm{mL} \text { water })\end{array}$} \\
\cline { 3 - 5 } & Hours of treatment & $\mathrm{LC}_{50}(\mu \mathrm{L} / \mathrm{mL}$ water $)$ & 1.6 & 3.5 \\
T. filifolia oil & 24 & 2.4 & 1.6 & 2.6 \\
& 72 & 2.0 & 2.4 & 2.8 \\
(E)-anethole & 24 & 2.6 & 2.1 & 2.3 \\
& 72 & 2.2 & 5.5 & 8.1 \\
estragole & 24 & 6.4 & 4.9 & 7.0 \\
DDVP & 72 & 5.6 & 0.00049 & 0.00057 \\
& 24 & 0.00053 & 0.00036 & 0.00043 \\
\hline
\end{tabular}

Table 3: Effect of Tagetes filifolia oil and its mains components on MDA and conjugated dienes content of Tribolium castaneum at $72 \mathrm{~h}$ after exposure.

\begin{tabular}{ccccc}
\hline Compounds & $\begin{array}{c}\text { Concentration } \\
(\mu \mathrm{L} / \mathrm{mL} \text { water })\end{array}$ & Mortality $(\%)$ & $\begin{array}{c}\text { MDA } \\
\left(\mathrm{mM} \mathrm{g} \text { insect weight }{ }^{-1}\right)\end{array}$ & $\begin{array}{c}\text { Conjugated Dienes } \\
(\text { Abs 232 nm) }\end{array}$ \\
\hline T. filifolia oil & 0 & $0 \mathrm{a}$ & $0.309 \pm 0.006 \mathrm{a}$ & $0,5234 \pm 0,0200 \mathrm{~b}$ \\
& 2.4 & $100 \mathrm{~b}$ & $0.344 \pm 0.006 \mathrm{~b}$ & $0,5224 \pm 0,0808 \mathrm{~b}$ \\
$($ E)-anethole & 3.0 & $100 \mathrm{~b}$ & $0.366 \pm 0.005 \mathrm{c}$ & $0,2363 \pm 0,0144 \mathrm{a}$ \\
& 0 & $0 \mathrm{a}$ & $0,297 \pm 0,005 \mathrm{a}$ & $0,4585 \pm 0,0081 \mathrm{~b}$ \\
estragole & 2.4 & $77 \pm 5 \mathrm{~b}$ & $0,317 \pm 0,007 \mathrm{a}$ & $0,4809 \pm 0,0063 \mathrm{~b}$ \\
& 3.0 & $97 \pm 3 \mathrm{c}$ & $0,377 \pm 0,007 \mathrm{~b}$ & $0,2458 \pm 0,0105 \mathrm{a}$ \\
& 0 & $0 \mathrm{a}$ & $0,297 \pm 0,005 \mathrm{a}$ & $0,4585 \pm 0,0081 \mathrm{bc}$ \\
& 2.4 & $0 \mathrm{a}$ & $0,293 \pm 0,005 \mathrm{a}$ & $0,4905 \pm 0,0065 \mathrm{c}$ \\
& 3.0 & $22 \pm 5 \mathrm{~b}$ & $0,301 \pm 0,002 \mathrm{a}$ & $0,4480 \pm 0,0170 \mathrm{ab}$ \\
\hline
\end{tabular}

Values (means \pm ES) having different letters in the same compound are significantly different from each other according to Duncan's multiple range test at $P \leq 0.05(n=3)$. 


\section{Inhibitory effect of monoterpenes on AChE activity}

In vitro inhibitory effect of phenylpropenes on AChE activity from adults $T$. castaneum was examined at $1 \mathrm{mM}$ and $5 \mathrm{mM}$. (E)-anethole and estragole showed similar inhibition (\%) at the two concentrations tested. Maximal inhibition was observed at $5 \mathrm{mM}$ (54-63\%) (Table 4).

\section{DISCUSSION}

A similar composition of the essential oil of $T$. filifolia from other regions was observed by other authors (Serrato-Cruz et al., 2008; Ruiz et al., 2010; Armas et al., 2012).

This study showed that $T$. castaneum adults are susceptible to fumigant action of T. filifolia $\mathrm{EO}$ and its pure component (E)-anethole. Besides, EO and (E)anethole were more effective than estragole. López et al. (2008) reported than anethole and estragole may have a synergized insecticide action when presented together as part of the EO. Nevertheless, in this study the EO and (E)-anethole have shown a similar activity (Table 2). The high content of (E)anethole in the EO could be the responsible of the bioactivity of this oil (Table 1). Previous studies founded that (E)-anethole and estragole showed similar insecticidal activity against $T$. castaneum adults (Ho et al., 1997; Chang et al, 2009; Mondal \& Khalequzzaman, 2010; Ebadollahi, 2011; Chu et al., 2012).

Natural or synthetic insecticides have different modes of action; increasing evidence for their secondary effects suggests that they disturb cellular homeostasis by generating free radical intermediates that trigger lipid peroxidation (Bakkali et al., 2008; Aslanturk et al., 2011; Yu et al., 2011; Leelaja \& Rajini, 2012; Prakash, 2015). The most commonly used criteria of oxidative stress are those based on determination of the concentrations of lipid oxidation products, usually polyunsaturated fatty acids, which are susceptible to attack by free radicals. In the present study, oxidative stress was evidenced principally in the different treatments by a significant increase in MDA content. However, concentrations of the different treatments did not have significant differences in CD content except at 3.0 $\mu \mathrm{L} / \mathrm{mL}$ water for $\mathrm{EO}$ and (E)-anethole, and at 5.2 $\mu \mathrm{L} / \mathrm{mL}$ water for estragole, in which they decreased (Table 3). This decrease may result from the fact that conjugated dienic hydroperoxides, the initial products of lipid peroxidation, are labile, unlike the more stable MDA (Aslanturk et al., 2011) formed upon their cleavage. An increase in MDA content has been shown with the use of different synthetic insecticides (Bakkali et al., 2008; Aslanturk et al., 2011; Yu et al., 2011; Leelaja \& Rajini, 2012). On the other hand, is known that the insecticidal activity of many terpenes and phenylpropanoids is directly related to their ability to inhibit the enzyme acetylcholinesterase. In this study, we showed an inhibition of insect AchE (> 60\%) at $5 \mathrm{mM}$ in the main EO components. López et al. (2015) reported the inhibitory effect of anethole and estragole on Electophorus and bovine erythrocyte AchE activity, respectively.

The insecticidal activity of EO and anethole at $24 \mathrm{~h}$ could indicate that the central nervous system (AChE, octopamine, GABA receptor, etc.) is one of their possible targets. Thus, the effect of anethole on AChE activity showed $60 \%$ of inhibition. On the other hand, estragole revealed low insecticidal activity at $24 \mathrm{~h}$ and high AChE inhibition. Similarly, Lee et al. (2001) did not find a direct correlation between insect toxicity against Sitophilus oryzae and AChE inhibition by menthone. Herrera et al. (2015) reported that camphor showed low insecticidal activity and high AChE inhibition. The same was observed by Yeom et al. (2012) with $\alpha$-pinene. Besides, Yeom et al. (2012) showed that (E)-anethole has not ability to inhibit this enzyme in cockroaches and López \& Pascual Villalobos (2010) showed the same but using electric eel AchE. This could be to the low penetration rate in the target site of the insect treated with these compounds. Therefore, oxidative stress could be involved in insect mortality at $72 \mathrm{~h}$ by estragol; due to this mechanism, do not cause an immediate effect in insect mortality. In addition, the values of MDA and CD content showed a correlation with insecticidal activity. So, oxidative stress is one of the possible mechanisms of target toxicity. Similar results were

Table 4: In vitro inhibition of Tribolium castaneum adult acetylcholinesterase by phenylpropenes.

\begin{tabular}{l|cc}
\hline Compounds & \multicolumn{2}{|c}{ AChE-inhibition (\%) } \\
\hline & $1 \mathrm{mM}$ & $5 \mathrm{mM}$ \\
(E)- anethole & $22.5 \pm 11.5 \mathrm{a}$ & $54.0 \pm 13.1 \mathrm{~b}$ \\
estragole & $8.3 \pm 7.9 \mathrm{a}$ & $63.0 \pm 1.5 \mathrm{~b}$ \\
\hline
\end{tabular}

Data (\%) are means \pm SE of three replicates. Different letters are significantly different from each other according to Duncan's multiple range test at $\mathrm{P} \leq 0.05$. 
reported by Prakash (2015) who revealed that the toxicity of EO of Rosmarinus officinalis against Sitophilus oryzae and Oryzaephilus surinamensis, might be associated with oxidative imbalance (antioxidant enzymes activity increased) and inhibition of AChE activity.

In conclusion, the data of the present study suggest that EO from T. filifolia and (E)-anethole present insecticidal activity and showed oxidative stress altering levels of MDA. Although other assays of oxidative stress must be analyzed, our recent results contribute to understanding the effect underlying the action of EO of T. filifolia and its principal components as oxidizing agents on insect. These findings suggest that the phenylpropanoids could act not only on AChE activity but also trigger oxidative stress.

The development of natural insecticides would help to decrease the negative impact of synthetic insecticides; because of their low toxicity, they do not generated the development of resistant populations of insects and they are safe to the environment despite their high relative cost and elevated doses compared with synthetic pesticide.

Based on these findings, EO from Tagetes filifolia and its main compound (E)-anethole may serve as viable alternatives to increase the lethality and effectiveness of currently available insecticides.

\section{ACKNOWLEDGEMENTS}

This research was supported by grants from Secretaría de Ciencia y Técnica de la Universidad Nacional de Córdoba and Consejo Nacional de Investigaciones Científicas y Técnicas (CONICET). J.M. Herrera and R. Olmedo hold a fellowship from CONICET. J.A. Zygadlo, M.P. Zunino, R.P. Pizzolitto and J.S. Dambolena are career members of CONICET.

\section{REFERENCES}

Abdelgaleil, S.A.M.; M.I.E. Mohamed, M.E.I. Badawi and S.A.A. El Arami, 2009. Fumigant and contact toxicities of monoterpenes to Sitophilus oryzae (L.) and Tribolium castaneum (Herbst) and their inhibitory effects on acetylcholinesterase activity. Journal of Chemical Ecology, 35:518-525.

Adams, P.R., 2007. Identification of essential oil components by gas chromatography/mass spectrometry. Allured Publishing Corp., Carol Stream, Illinois, USA.

Armas, K.; J. Rojas, L. Rojas and A. Morales, 2012.
Comparative study of the chemical composition of essential oils of five Tagetes species collected in Venezuela. Natural Products Communication, 7:12251226.

Arthur, F.H., 2012. Aerosols and contact insecticides as alternatives to methyl bromide in flour mills, food production facilities, and food warehouses. Journal of Pest Science, 85: 323-329.

Aslanturk, A.; S. Kalender, M. Uzunhisarcikli and Y. Kalender, 2011. Effects of methidathion on antioxidant enzyme activities and malondialdehyde level in midgut tissues of Lymantria dispar (Lepidoptera) larvae. Journal of the Entomological Research Society, 13: 27-38.

Bakkali, F.; S. Averbeck, D. Averbeck and M. Idaomar, 2008. Biological effects of essential oils- A review. Food and Chemical Toxicology, 46: 446-475.

Caballero-Gallardo, K.; J. Olivero-Verbel and E.E. Stashenko, 2011. Repellent activity of essential oils and some of their individual constituents against Tribolium castaneum. Herbst. Journal of Agricultural Food and Chemistry, 59:1690-1696.

Camarillo, G.R.; L.D.A. Ortega, M.A.C. Serrato and C.H. Rodríguez, 2009. Biological activity of Tagetes filifolia (Asteraceae) on Trialeurodes vaporariorum (Hemiptera: Aleyrodidae). Revista Colombiana de Entomología, 35: 177-184.

Cervera, C.; A.C. Maymó, R. Martínez-Pardo and M.D. Garcerá, 2003. Antioxidant enzymes in Oncopeltus fasciatus (Heteroptera: Lygaeidae) exposed to cadmium. Environmental Entomology, 32: 705-710.

Chang, C.L.; I.L.K. Cho and Q.X. Li, 2009. Insecticidal activity of basil oil, trans-anethole, estragole, and linalool to adult fruit flies of Ceratitis capitata, Bactrocera dorsalis, and Bactrocera cucurbitae. Journal of Economy Entomology, 102: 203-209.

Chu ,S.S.; J. Cao, Q.Z. Liu, S.S. Du, Z.W. Deng and Z.L. Liu, 2012. Chemical composition and insecticidal activity of Heracleum moellendorffii Hance essential oil. Chemija, 23: 108-112.

Di Rienzo, J.A.; F. Casanoves, M.G. Balzarini, L. Gonzalez, M. Tablada and C.W. Robledo, 2010. Infostat version 2010. Grupo Infostat, FCA, Universidad Nacional de Córdoba, Argentina.

Ebadollahi, A., 2011. Chemical constituents and toxicity of Agastache foeniculum (Pursh) kuntze essential oil against two stored-product insect pests. Chilean Journal Agricultural Research, 71:212-217.

Ellman, G.L.; D. Courtney, V. Andres and R.M. Featherstone, 1961. A new and rapid colorimetric determination of acetylcholinesterase activity. Biochemical Pharmacology, 7:88-95.

Enan, E.E., 2001. Insecticidal activity of essential 
oils: octopaminergic sites of action. Comparative Biochemistry and Physiology, 130: 325-337.

Enan, E.E, 2005. Molecular response of Drosophila melanogaster tyramine receptor cascade to plant essential oils. Insect Biochemistry and Molecular Biology, 35: 309-321

FAO, 1974. Boletín Fitosanitario de la FAO. Método provisional para gorgojos adultos importantes en cereales almacenados con malation o lindano. Método $N^{\circ} 15$ de la FAO, 22:127-137

Finney, DJ., 1971. Probit Analysis. Cambridge University Press, New York.

Herrera, J.M.; M.P. Zunino, J.S. Dambolena, R.P. Pizzolitto, N.A. Gañan, E.I. Lucini and J.A. Zygadlo, 2015. Terpene ketones as natural insecticides against Sitophilus zeamais. Industrial Crops and Products, 70: 435-442.

Ho, S.H.; Y. Ma and A. Huang, 1997. Anethole a potential insecticide from Illicium verum Hook f., against two stored product insects. International Pest Control, 39:50-51.

Jagadeesan, R.; P.J. Collins, G.J. Daglish, P.R. Ebert and D.I. Schlipalius, 2012. Phosphine resistance in the rust red flour beetle, Tribolium castaneum (Coleoptera: Tenebrionidae): Inheritance, Gene Interactions and Fitness Costs. PLoS ONE 7: e31582.

Jbilou, R.; H. Amri, N. Bouayad, N. Ghailani, A. Ennabili and F. Sayah, 2008.Insecticidal effects of extracts of seven plant species on larval development, a-amylase activity and offspring production of Tribolium castaneum (Herbst) (Insecta: Coleoptera: Tenebrionidae). Bioresource Technology, 99:959-964.

Krishna, A.; V. Prajapati, S. Bhasney, A.K. Tripathi and S. Kumar, 2005.Potential toxicity of new genotypes of Tagetes (Asteraceae) species against stored grain insect pests. International Journal of Tropical Insect Science, 25:122-128.

Lee ,S.E.; B.H. Lee, W.S. Choi, B.S. Park, J.G. Kim and B.C. Campbell, 2001. Fumigant toxicity of volatile natural products from Korean spices and medicinal plants towards the rice weevil, Sitophilus oryzae (L). Pest Management Science, 57:548-553.

Leelaja, B.C. and P.S. Rajini, 2012. Impact of phosphine exposure on development in Caenorhabditis elegans: Involvement of oxidative stress and the role of glutathione. Pesticide Biochemistry and Physiology, 104:38-43.

López, M.D.; J. Contreras and M. J. Pascual Villalobos, 2008. Toxic compounds in essential oils of coriander, caraway and basil active against stored rice pests. Journal of Stored Products Research, 44:273- 278.

López, M.D.; F.J. Campoy, M.J. Pascual-Villalobos, E. Muñoz-Delgado, and C.J. Vidal. 2015.
Acetylcholinesterase activity of electric eel is increased or decreased by selected monoterpenoids and phenylpropanoids in a concentration dependent manner. Chemico-Biological Interactions, 229: 36-43.

López M.D. and M. J. Pascual Villalobos. 2010. Mode of inhibition of acetylcholinesterase by monoterpenoids and implications for pest control. Industrial Crops and Products, 31: 284-288.

López, S.B.; M.L. López, L.M. Aragón, M.L. Tereschuk, A.C. Slanis, G.E. Feresin, J. A Zygadlo and A.A. Tapia, 2011. Composition and anti-insect activity of essential oils from Tagetes $L$ species (Asteraceae, Helenieae) on Ceratitis capitata Wiedemann and Triatoma infestans Klug. Journal of Agricultural Food and Chemistry, 59:5286-5292

Lorini, I.; P.J.Collins, G.J. Daglish, M.K. Nayak and H. Pavic, 2007. Detection and characterization of strong resistance to phosphine in Brazilian Rhyzopertha dominica (F.) (Coleoptera: Bostrichidae). Pest Management Science, 63:358-364.

Mondal, M. and M. Khalequzzaman, 2010. Toxicity of naturally occurring compounds of plant essential oil against Tribolium castaneum (Herbst). Journal of Biological Science, 10:10-17.

Opit, G.P.; T.W. Phillips, M. J. Aikins and M.M. Hasan, 2012. Phosphine resistance in Tribolium castaneum and Rhyzopertha dominica from stored wheat in Oklahoma. Journal of Economy Entomology, 105:1107-1114

Pimentel, M.A.G., L.R.D.A. Faroni, M.R. Tótola and R.N.C. Guedes, 2007. Phosphine resistance, respiration rate and fitness consequences in stored-product insects. Pest Management Science, 63: 876-881.

Prakash, K.S.B., 2015. Toxicity and biochemical efficacy of chemically characterized Rosmarinus officinalis essential oil against Sitophilus oryzae and Oryzaephilus surinamensis. Industrial Crops and Products, 74:817-823.

Rajashekar, Y.; N. Bakthavatsalam and T. Shivanandappa, 2012. Botanicals as Grain Protectants. Psyche (New York), article: 646740.

Rattan, R.S., 2010. Mechanism of action of insecticidal secondary metabolites of plant origin. Crop Protection, 29: 913 - 920.

Regnault-Roger, C.; C. Vincent and J.T. Arnason, 2012. Essential oils in insect control: Low-risk products in a high-stakes world. Annual Review Entomology, 57:405-424.

Ruiz, S.; O. Malagón, T. Zaragoza and E. Valarezo, 2010. Composition of the essential oils of Artemisia sodiroi Hieron., Siparuna eggersii Hieron., Tagetes filifolia Lag. and Clinopodium nubigenum (Kunth) Kuntze from Loja Ecuador. Journal Essential Oil Bearing Plants, 13:676-691. 
Serrato Cruz, M.Á.; F. Díaz Cedillo and J.S. Barajas Pérez, 2008. Composition of essential oil in germplasm of Tagetes filifolia Lag. from Central-South region of México. Agrociencia, 42: 277-285.

SPPSS Inc, 2008. SPSS-vs. 17. User's Guide.

Stefanazzi, N.; T. Stadler and A. Ferrero, 2011. Composition and toxic, repellent and feeding deterrent activity of essential oils against the stored-grain pests Tribolium castaneum (Coleoptera: Tenebrionidae) and Sitophilus oryzae (Coleoptera: Curculionidae). Pest Management Science, 67, 639-646.

Waliwitiya, R.; P. Belton, R A Nicholson, Lowenberger CA. 2010. Effects of the essential oil constituent thymol and other neuroactive chemicals on flight motor activity and wing beat frequency in the blowfly Phaenicia sericata. Pest Management Science, 66: 277-289.

Yeom, H.J.; J.S. Kang, G.H. Kim and I.K. Park, 2012. Insecticidal and acetylcholine esterase inhibition activity of Apiaceae plant essential oils and their constituents against adults of German cockroach (Blattella germanica). Journal of Agricultural Food and Chemistry, 60:7194-7203.

Yu Q.Y.; S.M. Fang, Z.D. Zuo, F.Y. Dai, Z. Zhang and C. Lu, 2011. Effect of organophosphate phoxim exposure on certain oxidative stress biomarkers in the silkworm. Journal of Economy Entomology, 104: 101-106.

Zunino, M. P. and J.A. Zygadlo, 2004. Effect of monoterpenes on lipid oxidation of maize. Planta, 219: 303-309. 